6. Pineda AM, Tianco EA, Tan JB et al. Oral pentoxifylline and topical clobetasol propionate ointment in the treatment of pretibial myxoedema, with concomitant improvement of Graves' ophthalmopathy. J Eur Acad Dermatol Venereol 2007: 21: 1441 -3.

7. Schwartz KM, Ahmed DD, Ahmed I et al. Development of localized myxedema in a skin graft. Int J Dermatol 2002; 41: 401-3.

8. Rapoport B, Alsabeh R, Aftergood D et al. Elephantiasic pretibial myxedema: insight into and a hypothesis regarding the pathogenesis of the extrathyroidal manifestations of Graves' disease. Thyroid 2000; 10: 685-92.

9. Smith TJ. Insights into the role of fibroblasts in human autoimmune diseases. Clin Exp Immunol 2005; 141: 388-97.

10. Bartalena L, Marcocci C, Bogazzi F et al. Use of corticosteroids to prevent progression of Graves ophthalmopathy after radioiodine therapy for hyperthyroidism. N Engl J Med 1989; 321: 1349-52.
Manuskriptet ble mottatt 21.4. 2008 og godkjent 20.11. 2008. Medisinsk redaktør Odd Terje

Brustugun.

\title{
Kommentar
}

\section{Hudforandringer som diagnostisk hjelpemiddel}

Hudmanifestasjoner ved autoimmune endokrine sykdommer kan sammen med god anamnese og kiniske undersøkelser raskt føre til korrekt diagnose, noe Tone Kristin Bergersen \& Cato Mørk illustrerer med sine kasuistikker. Ved Graves' sykdom som deres artikkel omhandler, dannes autoantistoffer mot thyreoideastimulerende hormon (TSH)- reseptoren. Oftest er autoantistoffene stimulerende og resultatet blir økt hormonproduksjon. De samme antistoffene er trolig også involvert i utviklingen av sykdom utenfor thyreoideakjertelen; høye nivåer av TSH-reseptorantistoffer trigger og vedlikeholder både oftalmopati og dermopati (pretibialt myksødem). Graves' sykdom inngår $i$ en gruppe autoimmune sykdommer der autoantistoffer enten stimulerer eller blokkerer reseptorer. Best kjent er autoantistoffer mot acetylkolinreseptoren ved myasthenia gravis og autoantistoffer mot spenningsregulerte kalsiumkanaler ved LambertEatons myastenisk syndrom, sistnevnte et paraneoplastisk fenomen ved småcellet lungekreft. Mindre kjent er stimulerende antistoffer mot kalsiumsensorreseptor på parathyreoideacellene som gir hypokalsemi (1) og nylig rapporterte inhiberende antistoffer mot melanocortin-4-reseptoren med overvekt til følge (2).

Også ved hypotyreose er forandringer i huden fremtredende. Ved uttalt hypotyreose øker glykosaminoglykanmengden i huden slik at et generelt myksødem utvikles. Dette er ofte best synlig periorbitalt i tidlig sta- dium (3); huden blir samtidig gulig misfarget av karotenopphopning. Leggene er ofte et predileksjonssted for autoimmune hudmanifestasjoner, slik det er for Graves' dermopati. Hos diabetikere finner man ofte nekrobiosis lipoidica lokalisert her. Dette er distinkte velavgrensede plakk med rødbrun farge og av varierende størrelse som vokser utover og ofte ulcererer. Årsaken er ukjent, men i likhet med Graves' dermopati, kan traume være utløsende. Erythema nodosum, en postinfeksiøs immunologisk reaksjon etter blant annet streptokokkinfeksjoner og tuberkulose, er typisk også lokalisert på leggenes forside.

Flekkvist hårtap (alopecia areata) og pigmenttap i hud (vitiligo) er hyppig assosiert med autoimmunitet (3), blant annet ved Graves' sykdom og type 1-diabetes, men også ved mange andre autoimmune sykdommer. Funn av vitiligo og alopesi bør føre legens tanke til autoimmun sykdom og disposisjon.

Det er likevel ikke alltid at hudmanifestasjonen i seg selv er immunologisk betinget. Ved primær binyrebarksvikt er et av de få typiske tegnene en uttalt hyperpigmentering av hudområder utsatt for soleksponering og friksjon, noe som gir den klassiske pigmenteringen av knoker og bøyefurene i hendene (4). Relatert til hyperpigmentering er også acanthosis nigricans som er hyperpigmenterte, fortykkede, papillære hudforandringer typisk lokalisert $\mathrm{i}$ armhule, lyske og nakke (3). Tilstanden ses ved overvekt med insulinresistens, eventelt type 2-diabetes.
Acanthosis nigricans kan også være et paraneoplastisk fenomen, hyppigst rapportert ved adenokarsinomer i gastrointestinaltractus og ved underlivskreft.

Vurdering av huden hører til en god klinisk undersøkelse. Mange autoimmune sykdommer, ikke bare de endokrine, gir hudforandringer som kan være nyttige diagnostiske hjelpemidler.

\section{Eystein Sverre Husebye}

eystein.husebye@helse-bergen.no

Institutt for indremedisin

Universitetet i Bergen

og

Medisinsk avdeling

Haukeland universitetssykehus

5021 Bergen

Oppgitte interessekonflikter: Ingen

\section{Litteratur}

1. Kifor O, McElduff A, LeBoff MS et al. Activating antibodies to the calcium-sensing receptor in two patients with autoimmune hypoparathyroidism. $J$ Clin Endocrinol Metab 2004; 89: 548-56.

2. Peter JC, Bekel A, Lecourt AC et al. Anti-melanocortin-4 receptor autoantibodies in obesity. J Clin Endocrinol Metab 2009: 94: 793-800.

3. Jabbour SA. Cutaneous manifestations of endocrine disorders: a guide for dermatologists. Am J Clin Dermatol 2003; 4: 315-31.

4. Løvås K, Husebye ES. Addison's disease. Lancet 2005: 365: 2058-61.

Manuskriptet ble mottatt 15.1. 2008 og godkjent 26.1. 2008. Medisinsk redaktør Odd Terje Brustugun. 